\title{
Tick cell lines: tools for tick and tick-borne disease research
}

Lesley Bell-Sakyi ${ }^{1}$, Erich Zweygarth ${ }^{2}$, Edmour F. Blouin ${ }^{3}$, Ernest A. Gould ${ }^{4}$ and Frans Jongejan $^{5,6}$

${ }^{1}$ Centre for Tropical Veterinary Medicine, Royal (Dick) School of Veterinary Studies, University of Edinburgh, Easter Bush Veterinary Centre, Roslin, Midlothian EH25 9RG, UK

${ }^{2}$ Onderstepoort Veterinary Institute, Private Bag X05, Onderstepoort 0110, South Africa

${ }^{3}$ Department of Veterinary Pathobiology, Center for Veterinary Health Sciences, Oklahoma State University, Stillwater, OK 74078, USA

${ }^{4}$ Centre for Hydrology and Ecology Oxford, Mansfield Road, Oxford OX1 3SR, UK

${ }^{5}$ Utrecht Centre for Tick-borne Diseases, Department of Infectious Diseases and Immunology, Faculty of Veterinary Medicine, Utrecht University, Yalelaan 1, 3584CL Utrecht, The Netherlands

${ }^{6}$ Department of Veterinary Tropical Diseases, Faculty of Veterinary Science, University of Pretoria, Private Bag X04, Onderstepoort 0110, South Africa

Over 40 cell lines are currently available from 13 ixodid and one argasid tick species. The successful isolation and propagation of several economically important tick-borne pathogens in tick cell lines has created a useful model to study interactions between tick cells and these viral and bacterial disease agents. Tick cell lines have already proved to be a useful tool in helping to define the complex nature of the host-vector-pathogen relationship. With the availability of genomics tools, tick cell lines will become increasingly important as a complement to tick and tick-borne disease research in vivo once genetic transformation and gene silencing using RNA interference become routine. 


\section{Article Outline}

Why tick cell lines?

Tick cell lines - what's available?

What can you do with tick cell lines?

Propagation of Ehrlichia and Anaplasma

Isolation of pathogens

Tick symbionts

Pathogen genomics and proteomics

The future - what else can be done with tick cell lines?

Acknowledgements

References

\section{Why tick cell lines?}

Ticks are of huge economic significance worldwide, both as harmful parasites in their own right and as vectors of many pathogenic viruses, bacteria and protozoa of medical and veterinary importance [1]. In vitro culture systems, particularly continuous cell lines derived from vector and host tissues, have an invaluable and irreplaceable role in many aspects of tick and tick-borne pathogen research, including basic parasite biology, hostvector-pathogen relationships and disease control. In the three decades since the first ixodid tick cell lines were established [2], the scope of their use has broadened from a focus on propagation of tick-borne pathogens to include studies on tick biology, genomics, proteomics and genetic manipulation. The actual and potential range of applications for tick cell lines in tick and tick-borne disease research has never been wider.

\section{Tick cell lines - what's available?}

Attempts to cultivate tick cells date back over 50 years. Early studies resulted in primary cultures of tick cells and/or tissues capable of survival for up to 6 months; their use for propagation of viruses and bacteria has been comprehensively reviewed [3] and [4]. Improvements in methodology over two decades led to the establishment of the first 
continuous tick cell lines from Rhipicephalus appendiculatus [2]. Twelve years ago, when the last general review of the role of tick cell lines in vector-pathogen research was published [5], 20 cell lines were available from eight ixodid tick species. They had been used for propagation of Borrelia burgdorferi, Rickettsia spp., tick-borne spiroplasmas and various arboviruses [3], [5] and [6]. There are now over 40 cell lines from 13 ixodid and, for the first time, one argasid tick species (Box 1, Table 1). The range of microorganisms, in particular prokaryotes, that can be propagated in tick cell lines has been extended and includes several bacterial pathogens of considerable medical and veterinary importance worldwide (Table 2).

\section{Box 1. What are tick cell lines like?}

Most of the currently available tick cell lines were established from embryonic cells, using simple methodology and making no attempt to select particular tissue types [3], [18] and [57]. Primary cell cultures initiated from moulting nymphs after removal of the digestive and excretory system tissues [2] and cultures of whole moulting larval explants ([25] and [27]) have also yielded continuous cell lines. As a result, tick cell lines generally comprise two or more cell types [7] that can be present in varying proportions both at different times within a single culture and at different passage levels (Figure I). This mixture of cells seems to be essential for survival of the culture; attempts to clone tick cells have failed [18]. Moreover, individual cells within a tick cell line have a tendency to gain or lose chromosomes without affecting their survival [2], [3] and [58]. 

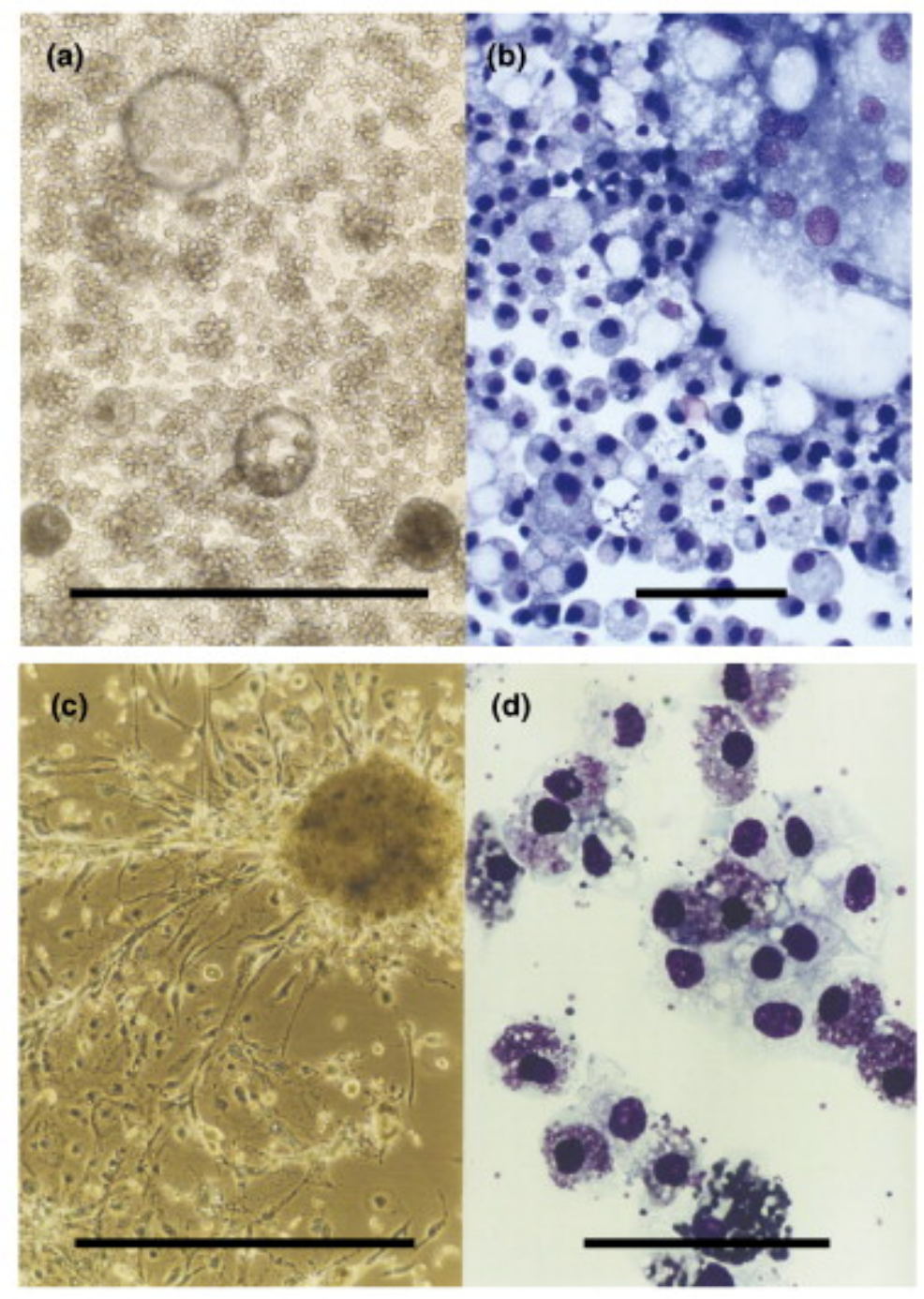

Figure I. (a,b) Ixodes ricinus cell line IRE/CTVM18; (c,d) Amblyomma variegatum cell line AVL/CTVM17. (a,c) Live phase contrast; the scale bar represents $500 \mu \mathrm{m}$; (b,d) cytocentrifuge smears stained with Giemsa; the scale bar represents $50 \mu \mathrm{m}$.

Tick cell lines share several characteristics with the arthropods from which they were derived. As befits haematophagous parasites, they grow in mammalian culture media supplemented with mammalian serum, at incubation temperatures between $28^{\circ} \mathrm{C}$ and $34^{\circ} \mathrm{C}$, although some lines will also grow at $37^{\circ} \mathrm{C}$. Some tick cell lines thrive in acidic conditions ( $\mathrm{pH}$ 6.5-6.8), similar to the environment of proliferating cells within developing larvae, nymphs and adults [5], whereas others are propagated at neutral to alkaline $\mathrm{pH}$, enabling growth of acid-sensitive pathogens [16]. Tick cells do not exhibit 
contact inhibition and most will grow readily in three dimensions; tick cells are generally not strongly adherent, growing as a combination of incomplete monolayer and suspension culture. They divide relatively slowly, can be maintained at high cell densities $\left(10^{6}-\right.$ $10^{7}$ cells $\mathrm{ml}^{-1}$ ), and many lines do not require regular subculture, making them particularly suitable for isolation of slow-growing microorganisms. Short-term storage at $12{ }^{\circ} \mathrm{C}[3]$ or even $4{ }^{\circ} \mathrm{C}[59]$ is often preferable to cryopreservation, as frozen tick cells can be difficult to resuscitate reliably [3] and [57]; however, cells cryopreserved in liquid nitrogen can survive for at least 12 years [18]. Individual cultures of some tick cell lines can be extremely long-lived, surviving for several years with regular medium changes and occasional subcultures, reflecting the ability of ixodid ticks to exist for extremely long periods of time between blood meals in nature.

Table 1.

Tick cell lines that are currently available ${ }^{\mathrm{a}}$

\begin{tabular}{|c|c|c|c|}
\hline Tick species & Instar & Cell lines & Refs \\
\hline Amblyomma americanum & Embryo & AAE2, 12 & [9] and [49] \\
\hline Amblyomma variegatum & Larva & AVL/CTVM13, 17 & [25] and [27] \\
\hline Boophilus decoloratus ${ }^{\mathrm{b}}$ & Embryo & BDE/CTVM16 & {$[25]$} \\
\hline \multirow[t]{3}{*}{ Boophilus microplus ${ }^{\mathrm{b}}$} & Embryo & $\begin{array}{l}\text { B. microplus IX, VII- } \\
\text { SCC }\end{array}$ & $\begin{array}{l}{[3],[13],[25] \text { and }} \\
{[62]^{\mathrm{c}}}\end{array}$ \\
\hline & & BME26 & \\
\hline & & BME/CTVM2, 4, 5, 6 & \\
\hline Carios capensis & Embryo & $\mathrm{CCE} 1,2,3,5$ & {$[9]^{\mathrm{d}}$} \\
\hline Dermacentor albipictus & Embryo & DALBE3 & {$[9],[16]$ and [42] } \\
\hline Dermacentor andersoni & Embryo & DAE3, 15,100 & [8] and [9] \\
\hline $\begin{array}{l}\text { Dermacentor (Anocentor) } \\
\text { nitens }\end{array}$ & Embryo & ANE58 & {$[3]$} \\
\hline Dermacentor variabilis & Embryo & DVE1 & {$[9]$} \\
\hline Hyalomma anatolicum & Embryo & HAE/CTVM7, 8, 9, 10, & {$[57]$} \\
\hline
\end{tabular}




\begin{tabular}{|l|l|l|l|}
\hline Tick species & Instar & Cell lines & Refs \\
\hline anatolicum & & 11 & \\
\hline Ixodes scapularis & Embryo & IDE2, 8, 12 & {$[18]$ and [63] } \\
\hline & & ISE5, 6, 18, 25 & \\
\hline Ixodes ricinus & Embryo & IRE11 & {$[10],[25]$ and [64] } \\
\hline & & IRE/CTVM18, 19, 20 & \\
\hline Rhipicephalus appendiculatus & Embryo & RAE25 & {$[3]$ and [25] } \\
\hline & & RAE/CTVM1 & \\
\hline & Nymph & RA243, 257 & {$[2]$ and [26] } \\
\hline Rhipicephalus sanguineus & Embryo & RSE8 & \\
\hline Actitional tick cell & & RAN/CTVM3 & {$[3]$} \\
\hline
\end{tabular}

${ }^{a}$ Additional tick cell lines mentioned in previous reviews [3] and [7] are, as far as the authors can ascertain, no longer available.

${ }^{\mathrm{b}}$ The genus Boophilus has been reclassified as a subgenus of Rhipicephalus; however, to avoid confusion over cell line nomenclature, Rhipicephalus (Boophilus) microplus and Rhipicephalus (Boophilus) decoloratus are referred to herein as B. microplus and B. decoloratus respectively.

${ }^{\mathrm{c}}$ L.B-S., unpublished.

${ }^{\mathrm{d}}$ T.J. Kurtti, unpublished (U.G. Munderloh, pers. commun.). 
Table 2.

Microorganisms propagated in tick cell lines since 1995

\begin{tabular}{|c|c|c|c|}
\hline $\begin{array}{l}\text { Microorganism } \\
\text { species }\end{array}$ & $\begin{array}{l}\text { Mammalian host } \\
\text { (disease caused) }\end{array}$ & Tick cell line(s) used & Refs \\
\hline Anaplasma marginale & Cattle (anaplasmosis) & $\begin{array}{l}\text { IDE8, ISE6, } \\
\text { IRE/CTVM18 }\end{array}$ & $\begin{array}{l}{[16],} \\
{[17],} \\
{[29],} \\
{[30],} \\
{[31],} \\
{[44],} \\
{[45] \text { and }} \\
{[61]}\end{array}$ \\
\hline $\begin{array}{l}\text { Anaplasma } \\
\text { phagocytophilum }\end{array}$ & $\begin{array}{l}\text { Domestic ruminants } \\
\text { (tick-borne fever), horses } \\
\text { (equine granulocytic } \\
\text { ehrlichiosis), humans } \\
\text { (human granulocytic } \\
\text { anaplasmosis) }\end{array}$ & IDE8, ISE6 & $\begin{array}{l}{[20],} \\
{[21],} \\
{[22],} \\
{[23],} \\
{[32],} \\
{[37],} \\
{[46],} \\
{[47] \text { and }} \\
{[52]}\end{array}$ \\
\hline Anaplasma ovis & Sheep (anaplasmosis) & IDE8 & {$[29]$} \\
\hline Anaplasma sp. & White-tailed deer & ISE6 & {$[33]$} \\
\hline $\begin{array}{l}\text { Anaplasma sp. } \\
\text { (Omatjenne) }\end{array}$ & Cattle & IDE8 & {$[30]$} \\
\hline Borrelia burgdorferi & $\begin{array}{l}\text { Rodents, dogs, humans } \\
\text { (Lyme disease) }\end{array}$ & ISE6, IDE8 & $\begin{array}{l}{[40] \text { and }} \\
{[41]}\end{array}$ \\
\hline Borrelia lonestari & $\begin{array}{l}\text { Humans (southern tick- } \\
\text { associated rash illness) }\end{array}$ & ISE6 & {$[34]$} \\
\hline Ehrlichia canis & $\begin{array}{l}\text { Dogs (canine } \\
\text { ehrlichiosis/tropical } \\
\text { canine pancytopaenia) }\end{array}$ & $\begin{array}{l}\text { IDE8, ISE6, } \\
\text { IRE/CTVM18 }\end{array}$ & $\begin{array}{l}{[19] \text { and }} \\
{[49]^{\mathrm{a}}}\end{array}$ \\
\hline Ehrlichia chaffeensis & $\begin{array}{l}\text { Humans (human } \\
\text { monocytic ehrlichiosis) }\end{array}$ & ISE6 & $\begin{array}{l}{[49] \text { and }} \\
{[50]}\end{array}$ \\
\hline Ehrlichia ruminantium & $\begin{array}{l}\text { Cattle, sheep, goats, wild } \\
\text { ruminants (heartwater, } \\
\text { cowdriosis) }\end{array}$ & $\begin{array}{l}\text { AVL/CTVM13, 17, } \\
\text { BDE/CTVM16, } \\
\text { BME/CTVM2, 6, IDE8, }\end{array}$ & $\begin{array}{l}{[24],} \\
{[25]} \\
{[26]}\end{array}$ \\
\hline
\end{tabular}




\begin{tabular}{|c|c|c|c|}
\hline $\begin{array}{l}\text { Microorganism } \\
\text { species }\end{array}$ & $\begin{array}{l}\text { Mammalian host } \\
\text { (disease caused) }\end{array}$ & Tick cell line(s) used & Refs \\
\hline & & $\begin{array}{l}\text { IRE/CTVM18, RAE25 } \\
\text { RAE/CTVM1, } \\
\text { RAN/CTVM3, }\end{array}$ & $\begin{array}{l}{[27],} \\
{[28] \text { and }} \\
{[48]}\end{array}$ \\
\hline Rickettsia rickettsii & $\begin{array}{l}\text { Humans (Rocky } \\
\text { Mountain spotted fever) }\end{array}$ & $\begin{array}{l}\text { IDE2, DALBE3, ISE6, } \\
\text { IDE8 }\end{array}$ & $\begin{array}{l}{[38],} \\
{[42] \text {, }} \\
{[64] \text { and }} \\
{[65]}\end{array}$ \\
\hline Rickettsia peacockii & & $\begin{array}{l}\text { DAE100, ISE6, BME26, } \\
\text { DVE1, DAE3, DAE15, } \\
\text { IDE12, IDE2, IDE8, } \\
\text { IRE11, CCE3 }\end{array}$ & $\begin{array}{l}{[8],[9],} \\
{[65] \text { and }} \\
{[66]}\end{array}$ \\
\hline Rickettsia monacensis & $?$ & $\begin{array}{l}\text { ISE6, IRE11, DAE100, } \\
\text { IDE8 }\end{array}$ & $\begin{array}{l}{[51] \text {, }} \\
{[64] \text { and }} \\
{[66]}\end{array}$ \\
\hline Rickettsia helvetica & $\begin{array}{l}\text { Humans (fever, } \\
\text { perimyocarditis?) }\end{array}$ & IRE11 & {$[64]$} \\
\hline Rickettsia montanensis & Various small mammals & IDE2, DALBE3 & {$[38]$} \\
\hline $\begin{array}{l}\text { Rickettsia sp. (spotted } \\
\text { fever group) }\end{array}$ & $?$ & RAE25, IDE2, IDE8 & [35] \\
\hline Rickettsia felis & $\begin{array}{l}\text { Humans (flea-associated } \\
\text { spotted fever) }\end{array}$ & ISE6 & {$[36]$} \\
\hline Wolbachia persica & & DALBE3 & {$[38]$} \\
\hline $\begin{array}{l}\text { Tick-borne } \\
\text { encephalitis virus }\end{array}$ & $\begin{array}{l}\text { Humans (tick-borne } \\
\text { encephalitis) }\end{array}$ & $\begin{array}{l}\text { RA257, ISE6, } \\
\text { RAE/CTVM1, } \\
\text { AVL/CTVM17, } \\
\text { IRE/CTVM18, }\end{array}$ & $\begin{array}{l}{[10] \text {, }} \\
{[11] \text {, and }} \\
{[60] \text { and }} \\
{[67]}\end{array}$ \\
\hline West Nile virus & $\begin{array}{l}\text { Horses, humans (West } \\
\text { Nile fever) }\end{array}$ & $\begin{array}{l}\text { ISE6, RAE/CTVM1, } \\
\text { AVL/CTVM17, } \\
\text { IRE/CTVM18 }\end{array}$ & {$[10]$} \\
\hline Powassan virus & $\begin{array}{l}\text { Humans (Powassan } \\
\text { fever/encephalitis) }\end{array}$ & $\begin{array}{l}\text { ISE6, RAE/CTVM1, } \\
\text { AVL/CTVM17, } \\
\text { IRE/CTVM18 }\end{array}$ & {$[10]$} \\
\hline Langat virus & $\begin{array}{l}\text { Rodents, experimentally } \\
\text { infected humans (Langat }\end{array}$ & $\begin{array}{l}\text { ISE6, RAE/CTVM1, } \\
\text { AVL/CTVM17, }\end{array}$ & {$[10]$} \\
\hline
\end{tabular}




\begin{tabular}{|c|c|c|c|}
\hline $\begin{array}{l}\text { Microorganism } \\
\text { species }\end{array}$ & $\begin{array}{l}\text { Mammalian host } \\
\text { (disease caused) }\end{array}$ & Tick cell line(s) used & Refs \\
\hline & encephalitis) & IRE/CTVM18 & \\
\hline Louping ill virus & $\begin{array}{l}\text { Sheep, other } \\
\text { domestic/companion } \\
\text { animals, grouse (Louping } \\
\text { ill encephalitis) }\end{array}$ & $\begin{array}{l}\text { ISE6, RAE/CTVM1, } \\
\text { AVL/CTVM17, } \\
\text { IRE/CTVM18 }\end{array}$ & {$[10]$} \\
\hline $\begin{array}{l}\text { Venezuelan equine } \\
\text { encephalitis virus }\end{array}$ & $\begin{array}{l}\text { Horses, humans } \\
\text { (encephalitis) }\end{array}$ & RAE/CTVM1 & {$[10]$} \\
\hline Dugbe virus & $\begin{array}{l}\text { Humans (fever), } \\
\text { domestic ruminants }\end{array}$ & ISE6 & {$[12]$} \\
\hline Hazara virus & $\begin{array}{l}\text { Humans (no disease but } \\
\text { related to Crimean- } \\
\text { Congo haemorrhagic } \\
\text { fever virus) }\end{array}$ & ISE6 & {$[12]$} \\
\hline Thogoto virus & $\begin{array}{l}\text { Humans (encephalitis), } \\
\text { domestic ruminants }\end{array}$ & $\begin{array}{l}\text { RAE/CTVM1, } \\
\text { BME/CTVM6, } \\
\text { HAE/CTVM99 }\end{array}$ & b \\
\hline
\end{tabular}

${ }^{a}$ E.Z., unpublished.

${ }^{\mathrm{b}}$ K. Hagmeier, G. Kochs, pers. commun.

Some tick species, such as R. appendiculatus and Boophilus microplus ${ }^{*}$, have yielded several cell lines in different laboratories (Table 1), whereas cells of other species have proved difficult to culture continuously [4], despite relatively standardized protocols for setting up primary cultures. Dermacentor andersoni, one of the first tick species used in cell culture experiments [7], did not yield a cell line until more than 30 years later [8]. Similarly, although soft (argasid) ticks have received much less attention overall than hard (ixodid) ticks [3] and [7], it has taken $\sim 30$ years to establish the first argasid cell lines [9]. Perhaps the most important ingredients contributing to success in establishing tick cell lines are: (i) patience - continuous cultivation can take up to 5 years from the time the primary culture is initiated, and the overall success rate is very low [4]; and (ii) operator experience - of the 44 cell lines listed in Table 1, 23 were established by T.J. Kurtti and U.G. Munderloh and 17 by L.B-S. 


\section{What can you do with tick cell lines?}

Virologists (Box 2) have been using R. appendiculatus cell lines for propagation and study of arboviruses for over 30 years [2], [4] and [6]; recently lines from several other tick species have also been applied successfully for this purpose [10], [11] and [12] (Table 2). Although tick cell lines have not yet been widely used in studies on tick physiology [3], the generation of organophosphate-resistant strains from the B. microplus cell line VII-SCC [13] provided an opportunity to study development in vitro of acaricide resistance in this species [14]. Immune-responsive c-type lysozymes were recently identified and characterized at the molecular level in the D. andersoni DAE100 cell line [15]. Whereas protozoologists have in the past found tick organ cultures to be a more suitable environment than cell cultures for in vitro development of tick-borne protozoa [3], bacteriologists have been the most comprehensive exploiters of tick cell lines during the past decade, aided by concurrent developments in molecular genomics and proteomics.

\section{Box 2. Virology and tick cell lines}

Tick cell lines have been used to study a variety of subjects relating to virus pathogenesis and virus evolution. For example, when arthropod-borne viruses (arboviruses) infect ticks and/or tick cell lines, they do not induce noticeable pathologic or cytopathic changes [6]. Moreover, tick-borne arboviruses readily establish persistent infections in tick cell lines, which can be subcultured indefinitely and remain infected throughout the period of subculture [6]. This contrasts with mammalian hosts in vivo and in vitro, for which arbovirus infection often results in death. The precise molecular basis for this difference in host response to virus infection has never been satisfactorily explained. However, in a recent publication [60] that compared the effects of tick-borne encephalitis virus on tick and mammalian cell lines, the virus maturation pathway was followed using immunoelectron microscopy. There were marked differences in the site of appearance of the individual structural virus proteins and also in their pattern of movement and dispersal through the infected cells. Cellular compartments remained almost completely intact in the tick cells, whereas in the mammalian cells, ultrastructural changes were marked and the cells died within $50 \mathrm{~h}$ of virus infection. 
A second feature of tick cell lines has often been exploited to isolate tick-borne viruses from field material. It is well known that the virus present in field material might not readily infect laboratory-maintained mammalian cell lines. On the other hand, tick cell lines are often susceptible to infection by the virus contained in field material. Thus, tick cell lines can be used successfully to isolate wild-type tick-borne viruses [3] and [6]. In addition, many mosquito-borne viruses will readily infect tick cells, whereas few tickborne viruses will grow in mosquito cells [3], [6] and [10]. This provides an additional diagnostic aid when isolating viruses from field material.

It has also been observed that tick-borne viruses evolve more slowly than mosquito-borne viruses, and this can be partly explained by the slower turnover of ticks (including virusinfected ticks), which can remain dormant for many months. However, the results of molecular studies of tick-borne viruses replicating in tick cells suggest that they do not undergo mutational changes at the same high frequency often seen in mammalian cells. Thus, in evolutionary terms, tick-borne arboviruses often characteristically evolve gradually (clinally).

\section{Propagation of Ehrlichia and Anaplasma}

The most significant recent developments in pathogen propagation in tick cell lines concern Ehrlichia and Anaplasma. Several members of these genera of obligately intracellular bacterial pathogens have been established in tick cell lines since 1995 (Table 2), among which Anaplasma marginale [16] and [17] has been most extensively exploited (Box 3). Continuous cultivation of these pathogens has been achieved in cell lines derived from various tick species, predominantly Ixodes scapularis [18]. Ehrlichia canis, the causative agent of canine ehrlichiosis, was successfully propagated in IDE8 cells [19] and, more recently, in Ixodes ricinus IRE/CTVM18 cells (E.Z., unpublished) (Figure 1a,b). Organisms derived from IDE8 cells remained infective, causing clinical ehrlichiosis in dogs; a cell line derived from the natural vector, Rhipicephalus sanguineus, did not become infected in vitro [19]. Ehrlichia equi, the human granulocytic ehrlichiosis agent, and Ehrlichia phagocytophila, all recently re-classified as Anaplasma phagocytophilum, have been successfully propagated in the I. scapularis cell lines IDE8 or ISE6 or both [20], [21] and [22]. Both the equine [20] and ovine [22] variants derived 
from tick cell cultures remained infective for their respective mammalian hosts, and antigen prepared from A. phagocytophilum-infected IDE8 cells was as sensitive and specific in ELISA as infected ovine granulocyte antigen [23]. The first continuous propagation of Ehrlichia ruminantium was carried out in IDE8 cells [24] and subsequently in cell lines from other non-vector species R. appendiculatus, Boophilus decoloratus ${ }^{*}$, B. microplus and I. ricinus and the vector species Amblyomma variegatum (Figure 1c,d) [25], [26] and [27]. After prolonged maintenance of E. ruminantium in tick cell cultures, some isolates could be re-established in bovine endothelial cell cultures [26]. Certain combinations of E. ruminantium and tick cell line were shown to have potential as a vaccine in sheep [28]. However, in subsequent trials the immunogenicity was lost for reasons that remain unclear and require further investigation (L.B-S., $\mathrm{PhD}$ thesis, Utrecht University, 2004). Anaplasma ovis, a pathogen of sheep and goats, was cultured in IDE8 cells and used to investigate the phenomenon of infection exclusion [29]. Recently a previously uncharacterized Anaplasma species, Anaplasma sp. (Omatjenne) from South Africa, was propagated continuously in IDE8 cells [30]. In the same study, an Israeli strain of $A$. marginale grew in both IDE8 and IRE/CTVM18 cells, the first report of continuous cultures of this pathogen in cells other than I. scapularis. Adaptation of A. marginale and A. phagocytophilum to growth in tick cells facilitated infection in vitro of mammalian endothelial cells, a host cell type not previously known to be invaded by these pathogens in vivo [31].

\section{Box 3. Anaplasma marginale in tick cell culture}

The first continuous in vitro culture system for the pathogen A. marginale was established in the I. scapularis cell line IDE8 from infected bovine erythrocytes [16]. Cultured A. marginale are infective for cattle and are potent antigens for use in vaccine preparations and serological tests. This model culture system for studying pathogen-host cell interactions in a controlled environment [17] has provided corroboration for in vivo studies, including:

- Infection and development of A. marginale in tick cells (Figure I): adhesion of the dense (infective) stage to the host cell membrane initiates an endocytotic process. After transformation to the reticulated stage and multiplication by binary fission, large colonies 
are formed. Colony membranes fuse with the host cell membrane and dense forms are released by exocytosis.
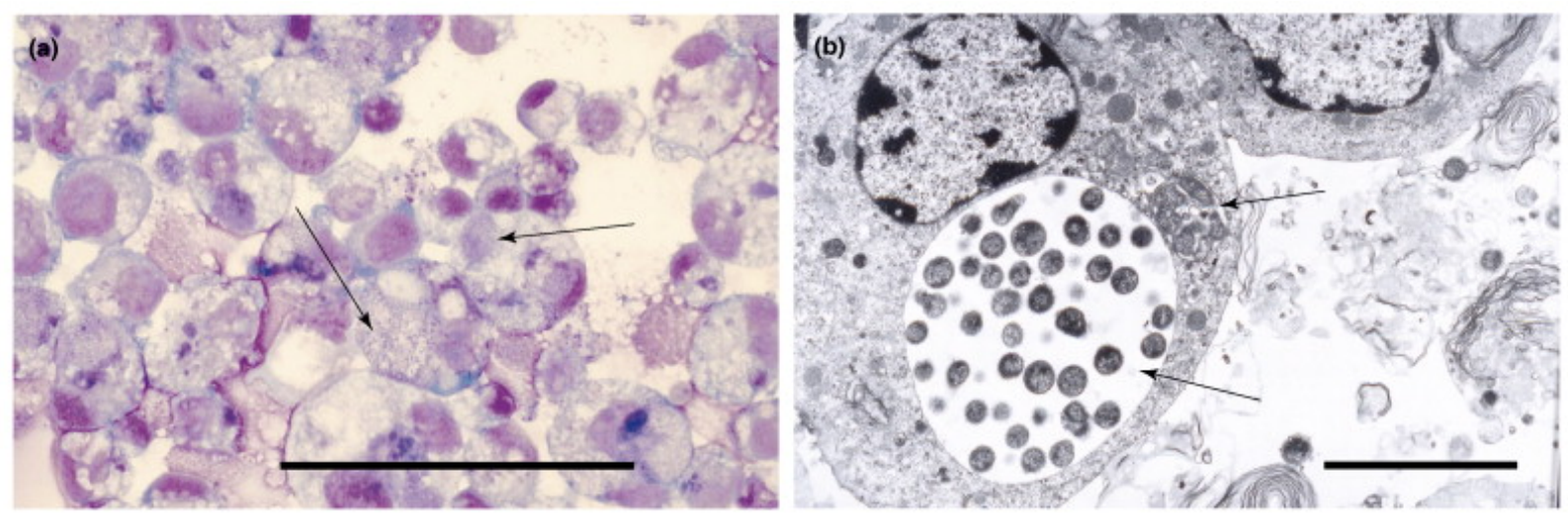

Figure I. Anaplasma marginale in IDE8 cells. (a) Cytocentrifuge smear stained with DiffQuick; the scale bar represents $50 \mu \mathrm{m}$; (b) transmission electron micrograph; the scale bar represents $5 \mu \mathrm{m}$. Arrows indicate bacterial colonies.

- Evaluation of the binding potential of two major surface proteins thought to be involved in adhesion to host cells (MSP1a and MSP1b): recombinant E. coli expressing the surface polypeptides was allowed to react with IDE8 cells. Adhesion assays indicated that MSP1a was an adhesin for tick cells, whereas MSP1b was not, suggesting that the role of the MSP1 complex varies between vertebrate and invertebrate hosts.

- Infection inhibition assay: antisera from naturally infected cattle or cattle immunized with erythrocytic $A$. marginale or with recombinant MSP1 complex did not inhibit infection of tick cells by $A$. marginale, whereas antisera from cattle or rabbits immunized with individual MSP1a and MSP1b significantly reduced infections [61].

- In vitro ELISA-based screening assay: evaluating the effects of tetracycline on parasite growth, enabling accurate quantification of infection levels in treated and untreated cultures, and demonstrating the infection-enhancing effect of phospholipase A2 from tick saliva in the cultured cells.

- Different geographic isolates established in culture have retained their unique MSP1a identity. Several isolates that are not infective for ticks were also not infective for IDE8 cells. Cultures infected with one isolate could not be subsequently infected with a second isolate demonstrating an infection exclusion phenomenon [29]. 


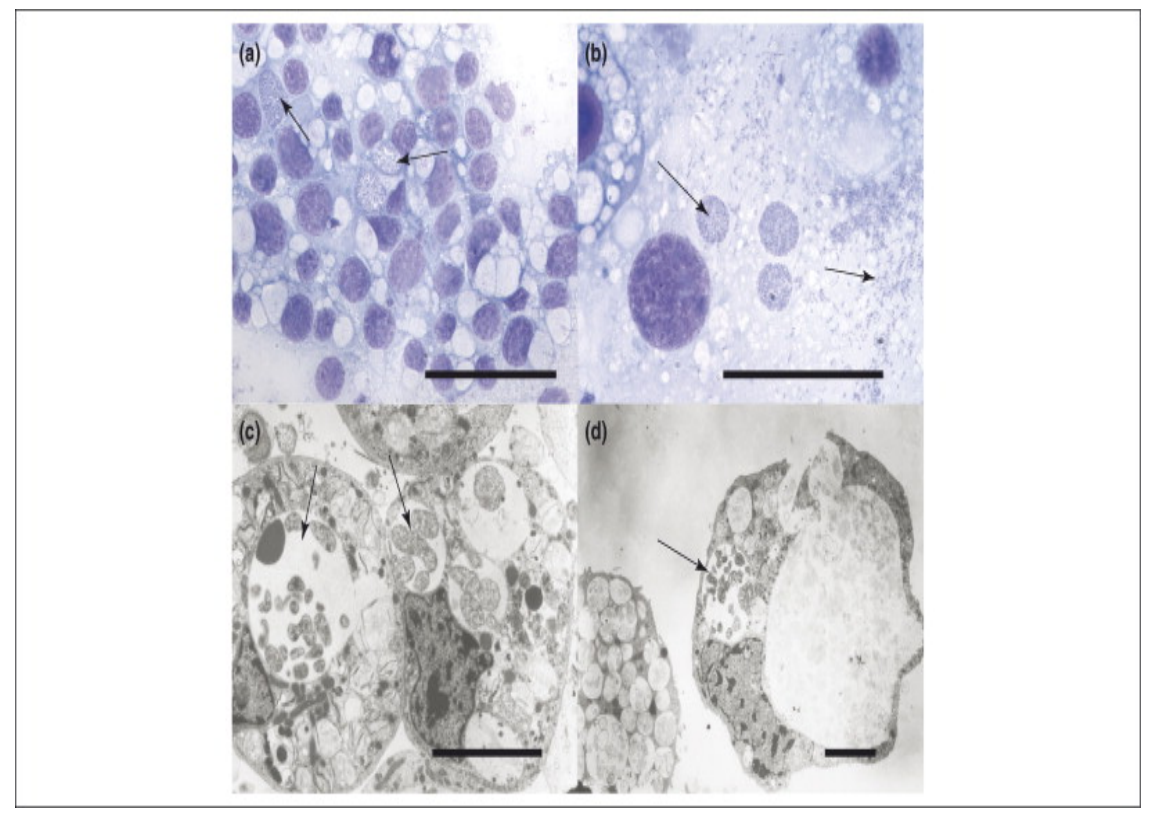

Figure 1. Ehrlichia spp. propagated in tick cell lines. (a) Ehrlichia canis in IDE8 cells; (b) E. canis in IRE/CTVM18 cells; (c) Ehrlichia ruminantium in IDE8 cells; (d) E. ruminantium in AVL/CTVM13 cell. $(\mathrm{a}, \mathrm{b})$ Cytocentrifuge smears stained with Giemsa; the scale bar represents $50 \mu \mathrm{m}$; (c,d) transmission electron micrographs; the scale bar represents $5 \mu \mathrm{m}$. Arrows indicate bacterial colonies.

\section{Isolation of pathogens}

In addition to being useful for propagation of pathogens, some of which cannot be grown in vitro in any other culture system, tick cell lines have application in isolation of previously uncharacterized tick-associated microorganisms from nature [3] and [6]. These actual and potential functions are facilitated by the range of tick species from which cell lines are now available, and the well-documented ability of some of these lines to support growth of microorganisms that are not transmitted by the parent tick, or even, in the case of some arboviruses, not transmitted by ticks at all [6], [10] and [25]. The first isolations of $A$. phagocytophilum from human blood were made using tick (IDE8) and human (HL60) cells [32]; although growth was initially much faster in the HL60 cells, the principle of isolating unknown pathogens using tick cells was established. Subsequently, a previously uncultivable Anaplasma sp. was isolated into ISE6 cells from 
the blood of white-tailed deer [33], and the same cell line was used for the first isolation of the aetiological agent of southern tick-associated rash illness in humans, Borrelia lonestari, by co-cultivation with tissues of the vector tick Amblyomma americanum [34]. Similarly, the R. appendiculatus cell line RAE25 was used to isolate a Rickettsia sp. of the spotted fever group by co-cultivation with midgut tissues from an $A$. americanum tick [35]. Very recently, the ISE6 cell line was used to isolate previously uncultivated strains of Rickettsia felis from cat fleas [36] and A. phagocytophilum from I. scapularis ticks [37].

\section{Tick symbionts}

Many ticks in the field have been found to harbour bacterial symbionts, which in some cases are closely related to known pathogens [38]. Rickettsia peacockii, an endosymbiont of $D$. andersoni that seems to interfere with transmission of $R$. rickettsii, was found to cause a chronic infection of the $D$. andersoni cell line DAE100 [8]. Several symbiotic and pathogenic Rickettsia species have been propagated in tick cell lines, facilitating characterization and investigation of their relationships with their host cells (Table 2). The I. scapularis cell line IDE2 was found to be chronically infected with a virus that has no detectable cytopathic effect on the tick cells and is presumably transmitted transovarially (vertically, from one generation to the next through the eggs) because IDE2 was embryo-derived [39]. This virus is also present in IDE8, but is absent from ISE6 (U.G. Munderloh, pers. commun.).

\section{Pathogen genomics and proteomics}

Tick cells provided an important environment for studies on stage-specific gene transcription and protein expression in B. burgdorferi; co-cultivation of spirochaetes with IDE8 and ISE6 cells influenced temperature-dependent outer surface protein expression associated with increased infectivity of spirochaetes for the mammalian host [40] and modulated transcription of genes involved with the starvation-associated stringent response [41]. Similarly, temperature-dependent protein expression was observed in $R$. rickettsii propagated in IDE2 and Dermacentor albipictus DALBE3 cells at both $28{ }^{\circ} \mathrm{C}$ 
and $34{ }^{\circ} \mathrm{C}$ [42]; the antigen profile in tick cells at $34{ }^{\circ} \mathrm{C}$ was similar to that seen in mammalian cells, whereas several proteins of unknown function present at the higher temperature were apparently not expressed at $28^{\circ} \mathrm{C}$.

In the search for A. marginale vaccine candidates, I. scapularis cell lines have had an essential role in many studies of differential gene transcription and outer membrane protein expression [43]. For example, levels of expression of the major surface proteins MSP1a and $1 \mathrm{~b}$ in tick cells and bovine erythrocytes correlated with their roles as adhesins for the different host cells [44], and levels of expression of outer membrane proteins encoded by the $m s p 2$ gene superfamily differed markedly between tick and bovine cells [45]. In A. phagocytophilum, the immunodominant p44 antigen predominated in human cells but not in tick cells and might be involved in regulatory changes that mediate survival of the pathogen by immune modulation after tick transmission [46]. The $p 44$ gene expression site was found to be polymorphic in human and tick cells, with sequence changes in p44 variants being influenced by host cell type and culture conditions [47]. Although all 16 members of the E. ruminantium major antigenic protein 1 (map1) multigene family were transcribed in vitro in mammalian cells, between 4 and 11 paralogs were transcribed in different tick cell lines [48]. Differential macrophage and tick cell-specific protein expression from the $\mathrm{p} 28 / \mathrm{p} 30$ outer membrane protein multigene locus in Ehrlichia chaffeensis and E. canis has been described [49]. Using proteomic approaches it was shown that proteins expressed in infected macrophages are the products of genes that differ from those expressed in infected tick cells [50].

\section{The future - what else can be done with tick cell lines?}

Tick cell lines have had a role in studies involving genetic manipulation of pathogens; $I$. scapularis cells infected with transformants of $R$. monacencis were found to be a useful system for studying interactions between rickettsiae and host cells [51], and induction of pathogen-derived resistance in ISE6 cells through silencing of tick-borne nairoviruses via RNA interference (RNAi) was described recently [12].

Genetic manipulation of tick cell lines per se has also been reported. Stable transfection, or transformation, of the ISE6 cell line to express a fluorescent protein was described [52] and [53]; the transformed tick cells supported growth of transformed $A$. 
phagocytophilum. Moreover, expression of the fluorescent protein by the transformed ISE6 cells was successfully silenced temporarily by RNAi [54]. Although there have been no published reports as yet of silencing of native tick genes in tick cell lines, RNAi has been shown to be functional in ticks and isolated tick tissues and is therefore an effective tool with which to study gene function at the tick-host-pathogen interface [55]. Silencing of genes in vitro in tick cell lines will create additional opportunities to investigate the functions of tick proteins at the cellular level. Moreover, in the search for previously unidentified, pharmacologically active proteins for anti-tick vaccines [56], it will be particularly useful to couple RNAi in ticks to high-throughput analysis in tick cells.

Although one must always be cautious when extrapolating from in vitro systems to whole ticks in vivo, further application of genomics tools such as RNAi and transfection (Box 4) to uninfected and pathogen-infected culture systems will increase the importance of the complementary role of tick cell lines in tick and tick-borne disease research.

\section{Box 4. Outstanding questions - what can be done to advance the use of tick cell lines as research tools?}

- Is there a need for more cell lines from ixodid tick species?

- Is there a need for more cell lines from argasid tick species?

- How can tick cell culture technology be made more accessible to the research community? Could this be achieved through a global repository for tick cell lines and training of a new generation of dedicated researchers in establishment and care of tick cell lines?

- How and why do individual cells in tick cell lines survive with aneuploid chromosome complements, and could this be exploited in determination of the function of individual genes?

- Can silencing of tick genes by RNAi be carried out on tick cell lines?

- Can additional tick cell lines be transfected and/or stably transformed and, if so, how can this be exploited?

-What role can tick cell lines play in development of anti-tick vaccines for domestic animals? 


\section{References}

1 F. Jongejan and G. Uilenberg, The global importance of ticks, Parasitology 129 (2004), pp. S3-S14.

2 M.G.R. Varma et al., The establishment of three cell lines from the tick Rhipicephalus appendiculatus (Acari: Ixodidae) and their infection with some arboviruses, J. Med. Entomol. 11 (1975), pp. 698-706.

3 T.J. Kurtti et al., Tick tissue and cell culture in vector research, Adv. Dis. Vector Res. 5 (1988), pp. 87-109.

4 M.G.R. Varma, Progress in the study of human and animal pathogens in primary and established tick cell lines. In: M. Mitsuhashi, Editor, Invertebrate Cell System Applications Vol. 2, CRC Press (1989), pp. 119-128.

5 U.G. Munderloh and T.J. Kurtti, Cellular and molecular interrelationships between ticks and prokaryotic tick-borne pathogens, Annu. Rev. Entomol. 40 (1995), pp. 221-243. 6 M. Pudney, Tick cell lines for the isolation and assay of arboviruses. In: C.E. Yunker, Editor, Arboviruses in Arthropod Cells in Vitro Vol. 1, CRC Press (1987), pp. 87-101. 7 C.E. Yunker, Preparation and maintenance of arthropod cell cultures: Acari, with emphasis on ticks. In: C.E. Yunker, Editor, Arboviruses in Arthropod Cells in Vitro Vol. 1, CRC Press (1987), pp. 35-51.

8 J.A. Simser et al., Isolation of a spotted fever group rickettsia, Rickettsia peacockii, in a Rocky Mountain wood tick, Dermacentor andersoni, cell line, Appl. Environ. Microbiol. 67 (2001), pp. 546-552.

9 T.J. Kurtti et al., Factors influencing in vitro infectivity and growth of Rickettsia peacockii (Rickettsiales: Rickettsiaceae), an endosymbiont of the Rocky Mountain wood tick, Dermacentor andersoni (Acari, Ixodidae), J. Invertebr. Pathol. 90 (2005), pp. 177186.

10 C.H. Lawrie et al., Susceptibility of mosquito and tick cell lines to infection with various flaviviruses, Med. Vet. Entomol. 18 (2004), pp. 268-274.

11 F. Senigl et al., Distribution of E and NS1 proteins of TBE virus in mammalian and tick cells, Folia Microbiol. (Praha) 49 (2004), pp. 213-216. 
12 S. Garcia et al., Nairovirus RNA sequences expressed by a Semliki Forest virus replicon induce RNA interference in tick cells, J. Virol. 79 (2005), pp. 8942-8947. 13 R. Cossio-Bayugar et al., In vitro generation of organophosphate resistant Boophilus microplus (Acari: Ixodidae) cell lines, J. Med. Entomol. 39 (2002), pp. 278-284. 14 R. Cossio-Bayugar et al., Basal cellular alterations of esterase, glutathione, glutathione $S$-transferase, intracellular calcium, and membrane potentials in coumaphos-resistant Boophilus microplus (Acari: Ixodidae) cell lines, Pestic. Biochem. Physiol. 72 (2002), pp. $1-9$.

15 J.A. Simser et al., Immune-responsive lysozymes from hemocytes of the American dog tick, Dermacentor variabilis and an embryonic cell line of the Rocky Mountain wood tick, D. andersoni, Insect Biochem. Mol. Biol. 32 (2004), pp. 1235-1246. 16 U.G. Munderloh et al., Establishment of the tick (Acari: Ixodidae)-borne cattle pathogen Anaplasma marginale (Rickettsiales: Anaplasmataceae) in tick cell culture, $J$. Med. Entomol. 33 (1996), pp. 656-664.

17 E.F. Blouin et al., Applications of a cell culture system for studying the interaction of Anaplasma marginale with tick cells, Anim. Health Res. Rev. 3 (2002), pp. 57-68. 18 U.G. Munderloh et al., Establishment, maintenance and description of cell lines from the tick Ixodes scapularis, J. Parasitol. 80 (1994), pp. 533-543.

19 Ewing, S.A. et al. (1995) Ehrlichia canis in tick cell culture. In Proceedings of the 76th Conference of Research Workers in Animal Diseases, Chicago, USA, 13-14 November 1995, abstract no. 165, Iowa State University Press.

20 U.G. Munderloh et al., Isolation of the equine granulocytic ehrlichiosis agent, Ehrlichia equi, in tick cell culture, J. Clin. Microbiol. 34 (1996), pp. 664-670.

21 U.G. Munderloh et al., Invasion and intracellular development of the human granulocytic ehrlichiosis agent in tick cell culture, J. Clin. Microbiol. 37 (1999), pp. $2518-2524$.

22 Z. Woldehiwet et al., Cultivation of an ovine strain of Ehrlichia phagocytophila in tick cell cultures, J. Comp. Pathol. 127 (2002), pp. 142-149.

23 Z. Woldehiwet and B.K. Horrocks, Antigenicity of ovine strains of Anaplasma phagocytophilum grown in tick cells and ovine granulocytes, J. Comp. Pathol. 132 (2005), pp. 322-328. 
24 L. Bell-Sakyi et al., Growth of Cowdria ruminantium, the causative agent of heartwater, in a tick cell line, J. Clin. Microbiol. 38 (2000), pp. 1238-1240.

25 L. Bell-Sakyi, Ehrlichia ruminantium grows in cell lines from four ixodid tick genera, J. Comp. Pathol. 130 (2004), pp. 285-293.

26 C.P.J. Bekker et al., Transcriptional analysis of the major antigenic protein 1 multigene family of Cowdria ruminantium, Gene 285 (2002), pp. 193-201.

27 L. Bell-Sakyi et al., Morphology of Cowdria ruminantium grown in two tick cell lines. In: M. Kazimirova, M. Labuda and P.A. Nuttall, Editors, Proceedings of the $3 r d$ International Conference 'Ticks and Tick-borne Pathogens: Into the 21st Century', Institute of Zoology, Slovak Academy of Sciences, Bratislava (2000), pp. 131-137. 28 L. Bell-Sakyi et al., Immunogenicity of Ehrlichia ruminantium grown in tick cell lines, Exp. Appl. Acarol. 28 (2002), pp. 177-185.

$29 \mathrm{~J}$. de la Fuente et al., Infection of tick cells and bovine erythrocytes with one genotype of the intracellular ehrlichia Anaplasma marginale excludes infection with other genotypes, Clin. Diagn. Lab. Immunol. 9 (2002), pp. 658-668.

30 E. Zweygarth et al., In vitro cultivation of a South African isolate of an Anaplasma sp. in tick cell cultures, Onderstepoort J. Vet. Res. 73 (2006), pp. 251-255.

31 U.G. Munderloh et al., Infection of endothelial cells with Anaplasma marginale and A. phagocytophilum, Vet. Microbiol. 101 (2004), pp. 53-64.

32 J.L. Goodman et al., Direct cultivation of the causative agent of human granulocytic ehrlichiosis, N. Engl. J. Med. 334 (1996), pp. 209-215.

33 U.G. Munderloh et al., Isolation of an Anaplasma sp. organism from white-tailed deer by tick cell culture, J. Clin. Microbiol. 41 (2003), pp. 4328-4335.

34 A.S. Varela et al., First culture isolation of Borrelia lonestari, putative agent of southern tick-associated rash illness, J. Clin. Microbiol. 42 (2004), pp. 1163-1169. 35 U.G. Munderloh et al., Microscopy of spotted fever rickettsia movement through tick cells, Microsc. Microanal. 4 (1998), pp. 115-121.

$36 \mathrm{~W}$. Pornwiroon et al., Rickettsia felis from cat fleas: isolation and culture in a tickderived cell line, Appl. Environ. Microbiol. 72 (2006), pp. 5589-5595.

37 R.F. Massung et al., Isolation of Anaplasma phagocytophilum strain AP-Variant 1 in a tick-derived cell line, Ann. N. Y. Acad. Sci. 1078 (2006), pp. 541-544. 
$38 \mathrm{H}$. Noda et al., Endosymbionts of ticks and their relationship to Wolbachia spp. and tick-borne pathogens of humans and animals, Appl. Environ. Microbiol. 63 (1997), pp. 3926-3932.

$39 \mathrm{H}$. Attoui et al., Complete sequence characterization of the genome of the St Croix River virus, a new orbivirus isolated from cells of Ixodes scapularis, J. Gen. Virol. 82 (2001), pp. 795-804.

40 M. Obonyo et al., Borrelia burgdorferi in tick cell culture modulates expression of outer surface proteins A and C in response to temperature, J. Clin. Microbiol. 37 (1999), pp. 2137-2141.

$41 \mathrm{~J}$. Bugrysheva et al., Modulation of Borrelia burgdorferi stringent response and gene expression during extracellular growth with tick cells, Infect. Immun. 70 (2002), pp. 3061-3067.

42 P.F. Policastro et al., Rickettsia rickettsii growth and temperature-inducible protein expression in embryonic tick cell lines, J. Med. Microbiol. 46 (1997), pp. 839-845. 43 K.A. Brayton et al., Genomic and proteomic approaches to vaccine candidate identification for Anaplasma marginale, Expert Rev. Vaccines 5 (2006), pp. 95-101. $44 \mathrm{~J}$. Garcia-Garcia et al., Differential expression of the mspla gene of Anaplasma marginale occurs in bovine erythrocytes and tick cells, Vet. Microbiol. 98 (2004), pp. 261-272.

45 S.M. Noh et al., Differential expression and sequence conservation of the Anaplasma marginale msp 2 gene superfamily outer membrane proteins, Infect. Immun. 74 (2006), pp. 3471-3479.

46 S.D. Jauron et al., Host cell-specific expression of a p44 epitope by the human granulocytic ehrlichiosis agent, J. Infect. Dis. 184 (2001), pp. 1445-1450.

47 A.F. Barbet et al., Expression of multiple outer membrane protein sequence variants from a single genomic locus of Anaplasma phagocytophilum, Infect. Immun. 71 (2003), pp. 1706-1718.

48 C.P.J. Bekker et al., Transcription analysis of the major antigenic protein 1 multigene family of three in vitro-cultured Ehrlichia ruminantium isolates, J. Bacteriol. 187 (2005), pp. 4782-4791. 
$49 \mathrm{~V}$. Singu et al., Unique macrophage and tick cell-specific protein expression from the p28/p30-outer membrane protein multigene locus in Ehrlichia chaffeensis and Ehrlichia canis, Cell. Microbiol. 8 (2006), pp. 1475-1487.

50 V. Singu et al., Ehrlichia chaffeensis expresses macrophage- and tick cell-specific 28kilodalton outer membrane proteins, Infect. Immun. 73 (2005), pp. 79-87.

51 G.D. Baldridge et al., Analysis of fluorescent protein expression in transformants of Rickettsia monacensis, an obligate intracellular tick symbiont, Appl. Environ. Microbiol. 71 (2005), pp. 2095-2105.

52 R.F. Felsheim et al., Transformation of Anaplasma phagocytophilum, BMC Biotechnol. 6 (2006), p. 42.

53 T.J. Kurtti et al., Stable transformation of a tick (Ixodes scapularis) cell line with the Sleeping Beauty transposon system, Soc. In Vitro Biol. J. 42 (2006), p. 32-A.

54 J.T. Mattila et al., RNAi-mediated silencing of a DsRed2-expressing Ixodes scapularis (Acari: Ixodidae) cell line, In Vitro Biol. J. 42 (2006), p. 32-A.

55 J. de la Fuente et al. (2007) RNA interference for the study and genetic manipulation of ticks. Trends Parasitol. (in press).

56 P. Willadsen and F. Jongejan, Immunology of the tick-host interaction and the control of ticks and tick-borne diseases, Parasitol. Today 15 (1999), pp. 258-262.

57 L. Bell-Sakyi, Continuous cell lines from the tick Hyalomma anatolicum anatolicum, J. Parasitol. 77 (1991), pp. 1006-1008.

$58 \mathrm{C}$. Chen et al., Cytogenetic characteristics of cell lines from Ixodes scapularis, J. Med. Entomol. 31 (1994), pp. 425-434.

$59 \mathrm{C} . \mathrm{V}$. Bastos et al., Use of refrigeration as a practical means to preserve viability of in vitro-cultured IDE8 tick cells, Exp. Appl. Acarol. 39 (2006), pp. 347-352.

$60 \mathrm{~F}$. Senigl et al., Differences in maturation of tick-borne encephalitis virus in mammalian and tick cell line, Intervirology 49 (2006), pp. 239-248.

61 E.F. Blouin et al., Antibodies to Anaplasma marginale major surface proteins 1a and 1 inhibit infectivity for cultured tick cells, Vet. Parasitol. 111 (2003), pp. 247-260.

62 P.J. Holman and N.C. Ronald, A new tick cell line derived from Boophilus microplus, Res. Vet. Sci. 29 (1980), pp. 383-387. 
63 T.J. Kurtti et al., Tick cell culture isolation of an intracellular prokaryote from the tick Ixodes scapularis, J. Invertebr. Pathol. 67 (1996), pp. 318-321.

64 J.A. Simser et al., Rickettsia monacensis sp. nov., a spotted fever group rickettsia, from ticks (Ixodes ricinus) collected in a European city park, Appl. Environ. Microbiol. 68 (2002), pp. 4559-4566.

65 G.D. Baldridge et al., Sequence and expression analysis of the ompA gene of Rickettsia peacockii, an endosymbiont of the Rocky Mountain wood tick, Dermacentor andersoni, Appl. Environ. Microbiol. 70 (2004), pp. 6628-6636.

66 G.D. Baldridge et al., Susceptibility of Rickettsia monacensis and Rickettsia peacockii to cecropin A, ceratotoxin A, and lysozyme, Curr. Microbiol. 51 (2005), pp. 233-238. $67 \mathrm{~J}$. Kopecky and I. Stankova, Interaction of virulent and attenuated tick-borne encephalitis virus strains in ticks and a tick cell line, Folia Parasitol. (Praha) 45 (1998), pp. $245-250$.

* The genus Boophilus has been reclassified as a subgenus of Rhipicephalus; however, to avoid confusion over cell line nomenclature, Rhipicephalus (Boophilus) microplus and Rhipicephalus (Boophilus) decoloratus will be referred to hereafter as B. microplus and B. decoloratus respectively. 